\title{
Challenges encountered by in-service K12 teachers at the beginning of the Covid-19 pandemic period: the case of Turkey
}

\author{
Nilgün Tosun* \\ Trakya University, Faculty of Education, CEIT Department, Kosova Campus, Edirne, Turkey \\ ORCID: 0000-0002-3470-858X
}

Can Mihc1

Trakya University, Faculty of Educaton, CEIT Department, Kosova Campus, Edirne, Turkey ORCID: 0000-0001-9393-4619

\section{Şahin Bayzan}

Turkish Information and Communication Technologies Authority, Eskisehir Yolu 10.Km No: 276, Çankaya, Ankara, Turkey

ORCID ID: 0000-0002-5610-0006

\begin{tabular}{ll}
\hline \hline Article history & \\
\hline Received: & \\
09.023 .2021 & \\
Received in revised form: & \\
18.04.2021 & Pccepted:
\end{tabular}

The aim of this study is to describe the negative experiences encountered by in-service K12 teachers in Turkey with respect to distance education practices applied urgently and compulsorily during the COVID-19 pandemic period. Analyses have been carried out on responses of teachers in order to determine the factors affecting them, so as to illustrate an example and to try to understand the impacts of decisions taken by the Turkish Ministry of National Education during the initial stages of the pandemic. The study follows a descriptive survey model and employs quota sampling based on the first level Nomenclature of Territorial Units for Statistics of Turkey. 1071 teachers participated in the study on a voluntary basis during the 30 March-1 June 2020 period by filling out a questionnaire form developed by the researchers. Quantitative and qualitative analyses of data were carried out via SPSS 24 and NVIVO 10 software, respectively. Findings indicate the most prominent problems reported by teachers are the lack of internet/device access by students as well as lack of experience of teachers with distance education. Analyses of problem frequency based on demographics have revealed that female teachers were more likely to suffer from the lack of IT skills. Teachers in the age group of $41+$, who belong to generation X, also tend to experience more problems due to the lack of IT skills in comparison with their younger peers. Moreover, issues such as internet and infrastructure inadequacies experienced in rural regions, low participation rate of students in the online courses, indifference of parents, and failure of teachers to be sufficiently active in the system, were considered as problems by the teachers; and solution suggestions have been presented accordingly.

\footnotetext{
* Correspondency: nilgunt@ hotmail.com
} 


\section{Introduction}

The declaration of Covid-19 as a pandemic by the World Health Organization (WHO) on March 11, 2020 has significantly affected all areas of life all over the world. Many issues requiring face-to-face interaction such as professional and social environments, communication and shopping habits, banking transactions, and health care examinations included in the daily routine of our lives had to be conducted on the internet during this process. Schools have also been closed in order to reduce the infection rate of the pandemic. By March 16, 2020, 762 thousand students in 109 countries were affected by the closure of schools, while a week later, the number of countries that closed their schools reached 155 and the number of students affected by this situation reached 987 thousand (UNESCO, 2020). As of 13 April 2020, the number of students affected by the closure of the schools in 192 countries has exceeded 1.5 billion (ILO, 2020). At the onset of the pandemic, at the national or regional level, many countries made decisions whether education should be conducted as distance education. For instance, the number of schools closed in 48 states of the United States of America at that time reached 124,000 (Casares, 2020). Unfortunately, in most South American countries except Brazil, Ecuador, Chile and Argentina, schools have had to close without any infrastructure for distance education (Macvicar, 2020). Although schools in Southeast Asia switched to distance education (Jalli, 2020), education continued in traditional school environment based on faceto-face interaction in Tajikistan and Turkmenistan (Levina, 2020). In Australia, it was agreed to let different states and regions decide for themselves as to whether schools within their territory should be closed and it was observed that schools with the necessary infrastructure decided to proceed with distance education (Wilson and Mude, 2020). Distance Education practices in the period of the pandemic between March to June 2020 by various countries of the world, according to a report by the World Bank (2020) have been summarized in Table 1.

Table 1. Distance Education Practices of Countries in the Early Period of the Pandemic

\begin{tabular}{|c|c|c|c|c|c|c|c|c|c|}
\hline Country & Internet & $\mathrm{Tv}$ & Radio & $\begin{array}{l}\text { Audio } \\
\text { Recordings }\end{array}$ & $\begin{array}{l}\text { Printed } \\
\text { Material }\end{array}$ & $\begin{array}{l}\text { Internet } \\
\text { Support }\end{array}$ & $\begin{array}{l}\text { Device } \\
\text { Support }\end{array}$ & $\begin{array}{l}\text { Psychological } \\
\text { Support }\end{array}$ & $\begin{array}{l}\text { Technical } \\
\text { Support }\end{array}$ \\
\hline Afghanistan & & $\sqrt{ }$ & $\sqrt{ }$ & $\sqrt{ }$ & $\sqrt{ }$ & & & & \\
\hline Argentina & & $\sqrt{ }$ & $\sqrt{ }$ & & & Student & Student & & \\
\hline Austria & $\sqrt{ }$ & $\sqrt{ }$ & & & & & & $\begin{array}{l}\text { Student- } \\
\text { Teacher }\end{array}$ & \\
\hline Bangladesh & $\sqrt{ }$ & $\sqrt{ }$ & $\sqrt{ }$ & & & & & & \\
\hline Brazil & $\sqrt{ }$ & $\sqrt{ }$ & & & & & & & \\
\hline Bulgaria & $\sqrt{ }$ & $\sqrt{ }$ & & & & & & & $\sqrt{ }$ \\
\hline Czech & $\sqrt{ }$ & $\sqrt{ }$ & & & & & & & \\
\hline Republic & & & & & & & & & \\
\hline China & $\sqrt{ }$ & $\sqrt{ }$ & & & & Student & & & \\
\hline Dominican & $\sqrt{ }$ & $\sqrt{ }$ & & & & & & & \\
\hline Republic & & & & & & & & & \\
\hline Ecuador & $\sqrt{ }$ & $\sqrt{ }$ & $\sqrt{ }$ & & & & & & \\
\hline Indonesia & $\sqrt{ }$ & $\sqrt{ }$ & & & & & & & \\
\hline Ethiopia & & $\sqrt{ }$ & $\sqrt{ }$ & & & & & & \\
\hline Fiji & & & $\sqrt{ }$ & & & & & & \\
\hline Finland & $\sqrt{ }$ & & $\sqrt{ }$ & & & & & & \\
\hline Georgia & $\sqrt{ }$ & $\sqrt{ }$ & & & & & & & \\
\hline Croatia & $\sqrt{ }$ & & $\sqrt{ }$ & & & Student & & & $\sqrt{ }$ \\
\hline India & $\sqrt{ }$ & $\sqrt{ }$ & & & & & & & \\
\hline Spain & $\sqrt{ }$ & $\sqrt{ }$ & & & & & & & \\
\hline Cambodia & $\sqrt{ }$ & $\sqrt{ }$ & & & & & & & \\
\hline Kenya & $\sqrt{ }$ & $\sqrt{ }$ & $\sqrt{ }$ & & & $\begin{array}{l}\text { Student- } \\
\text { Teacher }\end{array}$ & & & \\
\hline Kyrgyzstan & $\sqrt{ }$ & $\sqrt{ }$ & & & & & & & \\
\hline Colombia & $\sqrt{ }$ & $\sqrt{ }$ & $\sqrt{ }$ & & & & & & \\
\hline Korea & $\sqrt{ }$ & $\sqrt{ }$ & $\sqrt{ }$ & & & & & & \\
\hline Costa Rica & $\sqrt{ }$ & $\sqrt{ }$ & & & & & & & \\
\hline Kuwait & & $\sqrt{ }$ & & & & & & & \\
\hline
\end{tabular}




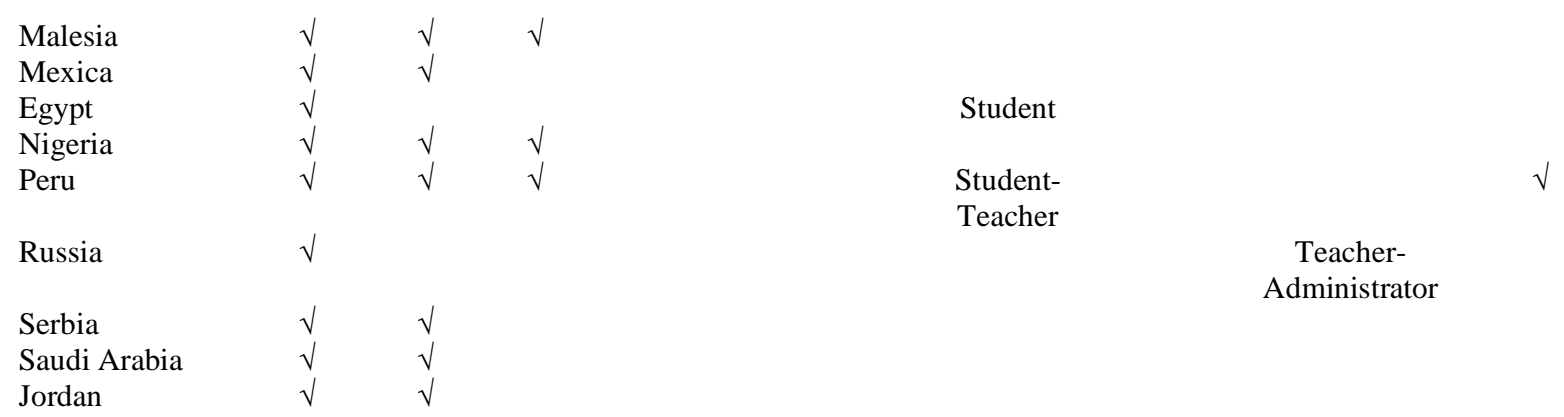

Distance education efforts at the early stages of the pandemic began unexpectedly and caught decision makers, administrators, teachers, students and parents off guard. This situation caused disruption of distance education from time to time and even resulted in complete inaccessibility. Although the devoted efforts of teachers in performing their duties are highly valuable and cannot be ignored; the lack of awareness, knowledge, experience and preparation of teachers conducting distance education is one of the factors that caused the problems experienced. That said, it is anticipated that distance education will be an integral part of the education system of many countries after the pandemic. Therefore, identifying the factors that prevent teachers from performing effective distance education and determining their views and demands in order to eliminate these obstacles is crucial for both the improvement of the ongoing distance education and the effectiveness and success of the distance education planned to continue in the coming years. Supporting the aforementioned process by means of the academic research and analyses may help facilitate the work of decision makers and provide them with informed guidance.

Numerous studies have been conducted to assess the emergency remote education process at the beginning of the Covid-19 pandemic from the perspective of teachers (e.g., Alea, Fabrea, Roldan \& Farooqi, 2020; An, Kaplan-Rakowski, Yang, Conan, Kinard, \& Daughrity, 2020; Code, Ralph and Forde, 2020; Doghonadze, Aliyev, Halawachy, Knodel \& Adedoyin, 2020; Khlaif, Salha, Affouneh, Rashed \& ElKimishy, 2020; Klapproth, Federkeil, Heinschke \& Jungmann, 2020; Kinard and Mahaffey, 2020; Kiptala and Kipruto, 2020; Lindner, Clemons, Thoron \& Lindner, 2020; Lionarakis vd., 2020; Mukhter and Chowdhary, 2020; Nalaskowski, 2020; Nambiar, 2020; Ng, Klavina, Ferreira, Barrett, Pozeriene \& Reina, 2021; Noor, Isa \& Mazhar, 2020; Phillips, 2020; Shraim and Crompton; 2020; Teymori and Fardin, 2020). When studies conducted in Turkey on teachers who performed their duties through distance education during the pandemic period are examined, it is observed that they are mostly limited by teachers, academics or private school teachers specialized in a specific subject and/or working in a specific city (e.g., Alper, 2020; Bakioğlu and Çevik, 2020; Başaran, Doğan, Karaoğlu \& Şahin, 2020; Bayburtlu, 2020; Can and Köroğlu, 2020; Çiftçi and Demir, 2020; Koçoğlu, Ulu Akın, Tekdal \& Yiğen, 2020; Korkmaz and Toraman, 2020; Moçoşoğlu and Kaya, 2020; Osmanoğlu, 2020; Sarı and Nayır, 2020). In the literature, we have not encountered a study with broader participation of teachers from all regions of Turkey who worked during the distance education process. In this context, it can be argued that this study, which is based on a sample statistically representing the entire nation of Turkey, is original and significant in terms of revealing the current situation from a broader perspective and illustrating an example case for the international community.

\section{The Aim of the Study}

The general aim of this study is to describe the negative experiences encountered by K12 teachers in the context of remote education practices, the transition of which was performed urgently and compulsorily in a state of emergency during the COVID-19 pandemic, 
and to examine the factors affecting these by illustrating an example case of Turkey and lastly to describe the decisions taken during the pandemic process as well as their effects. It is believed that doing so will contribute to the scientific literature of distance education. In accordance with the aim of the study, answers to the following questions were sought:

(1) Which are the most commonly encountered problems experienced by K12 teachers in the emergency remote education process in Turkey during the pandemic?

(2) Do the common problems encountered by Turkish K12 teachers in emergency remote education activities during the pandemic differ according to demographic variables such as gender, age, school level, education level and the location of the institution?

(3) According to the Turkish K12 teachers, how can the current distance education system in Turkey be improved?

Recommendations will be presented to improve the distance education dimension of national education systems based on the example of Turkey involving the answers given to the above questions. It is anticipated that these recommendations will guide decision-makers.

\section{Transition Process to Distance Education and Practices in The Early Period of the Pandemic in Turkey}

In order to understand research results from a cause-and-effect perspective this part of the study includes brief information regarding the transition process to emergency remote education in Turkey as well as the technologies used and the services provided to students, teachers and the parents during the period of distance education between March and June 2020.

\section{Transition to Emergency Remote Education}

On March 12, 2020 it was announced by the Presidency of the Republic of Turkey that the primary, secondary and high school level schools were suspended for 1 week as of March 16,2020 , and that education at these levels will be conducted as distance education as of March 23, 2020 within the scope of Covid-19 measures. During the said announcement, it was stated that this process, where the education would be carried out on the internet and via TV broadcasts, was planned as just 1 week (Presidency of the Republic of Turkey, 2020). Through the press release of MEB (the Turkish Ministry of National Education) dated March 25, 2020, it was announced that a decision was taken regarding the distance education to be carried out until April 30, 2020 (Turkish Ministry of National Education, 2020a). Approximately one month after this announcement, MEB stated that schools would not be opened, and that distance education would continue until 31 May 2020 (Turkish Ministry of National Education, 2020b). The 2019-2020 spring semester was completed through distance education at the primary, secondary and high school levels due to the aforementioned decisions. According to Statistics data of MEB with the closure of 68,589 schools, a total of 18,241,881 students and 1,117,686 teachers (Turkish Ministry of National Education, 2020c) enrolled in pre-school, primary, secondary and high schools were affected by the pandemic.

\section{Technologies Used and Services Provided for Emergency Remote Education}

\section{Education Information Network (EBA)}

Education Information Network (EBA) platform used for distance education since the beginning of the pandemic, was introduced to students, teachers and parents for free of charge in 2012 by the Directorate General of Innovation and Education Technologies unit under MEB. 
EBA, which is an online learning platform, can be accessed from any type of computer and mobile devices with Android or iOS. The main reasons for using EBA have been listed as a) establishing a rich e-content pool suitable for entire grade levels and different learning styles, b) spreading the culture of information technology, c) integrating information technology into education, and d) ensuring the exchange of information and ideas by encouraging teachers to develop e-content (Boz, 2016; İzmir İl MEM, 2019). Students, teachers and parents can access the platform at the web address of https://eba.gov.tr, by logging in with a username and password, after which they can perform activities such as learning, teaching and sharing information as per their authorized roles. On the main page of the platform, the content of the courses taught is displayed alongside the daily and weekly EBA TV broadcast schedules. Moreover, students can connect to their video conferencing based live online courses over EBA. All users can also get answers to questions regarding both the platform and the overall distance education process from the Frequently Asked Questions section.

In the early stages of the pandemic, a total broadcast time of 1 hour per day was allowed for $12^{\text {th }}$ grade courses and the same course kept on repeating for the remainder of the day. During the same period, the access of students from pre-school to 7th grade to EBA was restricted for certain periods of day, while no restrictions applied to students of grades 8-12 (due to the fact that at these grade levels students prepare for high stakes national exams) [A2]. This is believed to be due to infrastructure related problems caused by inadequate scaling, which were solved over time. As of June 15, EBA became accessible to all students for all 7 days of the week and 24 hours of the day (Directorate General of Innovation and Educational Technologies, 2020).

\section{Television Broadcasts}

Another distance education tool used during the pandemic period in Turkey was the television. TV broadcast was delivered to students in cooperation with the Turkish Radio and Television Association (TRT), the national TV broadcasting company of the government, which has dedicated TV channels for this purpose. The exist 6 designated channels entitled TRT EBA TV Primary School, TRT EBA TV Secondary School and TRT EBA TV High School (with HD and SD channel versions each). Broadcasts can also be accessed from channel frequencies of private TV broadcasters. Students could watch the broadcasts they missed on the official website of EBA or TRT. The lectures are carried out by teachers with established success in their profession, selected by the Ministry of National Education (EBA, 2021a).

\section{EBA Academic Support System (ADES)}

The EBA Academic Support System (ADES) is a free platform developed to support 11 th and 12th grade students' preparation for nationwide university entrance exams, more in the style of a cram school for this purpose. The most important feature of the platform is that it is reported to have an intelligent system that determines the current knowledge level and needs of the student in order to create a personalized study plan tailored to their needs. Students then are supported with customized lecture videos, Q\&A videos, or videos containing worked examples particularly in the form of questions asked in university entrance exams of previous years (EBA, 2021b).

\section{Technical Support}

In order to solve technical problems experienced by teachers, students, parents and administrators, the Ministry as well as provincial administrations have launched initiatives. One of these is the EBA Assistant, an artificial intelligence-supported troubleshooting application 
accessible over the EBA network, which has been developed to instantly answer questions of technical nature related to EBA and EBA TV (Turkish Ministry of National Education, 2020d). Another solution is the Help menu accessed from the EBA home page. The menu explains the answers to various technical questions in detail, from creating a password for logging in to EBA to even commonly encountered operating system problems not related to EBA. The EBA Control Center, established in the early period of the pandemic, is also an important solution product that works $24 / 7$. The duty of the center is to intervene immediately in problems that may occur in data centers due to congested network traffic, heavy user demand, cyber-attacks and the like, and to ensure the sustainability of distance education. Users can send their questions to the center via destek@eba.gov.tr e-mail address (Turkish Ministry of National Education, 2020e). In fact, an important technical problem experienced in the early pandemic period was related to internet connectivity, especially in cases where there are more than one K12 student, or a K12 student and teacher living in the same house. Data quotas on home or mobile networks are enforced by internet service providers, which when exceeded impose financial penalties, cause burden on family budgets. In order to solve this problem, MEB has allocated all home and mobile users a 3 GB extra data quota to be used only for the purpose of accessing EBA. In addition, leading GSM companies of the country have also launched campaigns and offered monthly free access to EBA packages between 3- 8 GB sizes to be used solely for access to EBA. Some GSM companies removed the quota limit altogether for EBA access and automatically increased the bandwidth of fiber users trying to access the platform to 100 MBits (Hürriyet, 2020; Turkish Ministry of National Education, 2020e; MebNews, 2020). A software application developed by Turkish teachers, which translates Latin text into Braille alphabet, was distributed free of charge to visually impaired students in the process (Turkish Ministry of National Education, 2020f). Eventually EBA Support Centers were established, where students without a device or internet connection could get help and even use resident devices to access the EBA network. The contact details of EBA support centers and Mobile support units were accessible at http://ebadesteknoktasi.meb.gov.tr/

\section{Method}

\section{Research Method}

The study follows a descriptive-survey research model. Descriptive-survey is used for studies conducted on large groups, in which the views and attitudes of the individuals in the group about a phenomenon or event are recorded, and the relevant phenomenon and events therefore described (Karakaya, 2012:59). In the descriptive-survey model, the variables in the research are defined as they exist without any intervention, i.e., without changing or affecting the very situation (Fraenkel and Wallen, 2006; Karasar, 1998).

\section{Sample}

In order to assure the representation of the sample size in Turkey, a quota sampling strategy, prepared by considering the first level Nomenclature of Territorial Units for Statistics of Turkey (IBBS Turkey) developed in accordance with the European Statistical System (ESS), was followed. In quota sampling, samples with certain variables considered to determine the characteristics of the population are taken into account (Gürbüz, 2018; Kılıç, 2013). The number of participants expected to be included in the study weas determined by the quota sampling principle proportionately with population statistics of 12 territorial units found in IBBS Turkey. Participants were reached with convenience sampling method. In convenience sampling, participants are selected on the basis of convenience and ease of access. Data 
collection continued until the number of people to be included in the sample reached the desired quota size (Gürbüz, 2018). At the end of this study, a sample size of 1071 in-service K12 teachers has been reached, representing all regions of Turkey proportionately based on population. The demographic characteristics of the sample are given in Table 2.

Table 2. Demographic Characteristics of the Study Group

\begin{tabular}{|c|c|c|c|}
\hline Demographic Characteristics & & Frequency & Percentage \\
\hline \multirow{2}{*}{ Gender } & Female & 591 & 55.2 \\
\hline & Male & 480 & 44.8 \\
\hline \multirow{2}{*}{ Age Category } & $21-40$ & 708 & 66.1 \\
\hline & $41+$ & 363 & 33.9 \\
\hline \multirow{3}{*}{ School Type } & Primary School $\left(1^{\text {st }}-4^{\text {th }}\right.$ grades $)$ & 249 & 23.2 \\
\hline & Secondary School $\left(5^{\text {th }}-8^{\text {th }}\right.$ grades $)$ & 639 & 59.7 \\
\hline & High School $\left(9^{\text {th }}-12^{\text {th }}\right.$ grades $)$ & 183 & 17.1 \\
\hline \multirow{2}{*}{ Education Level } & Bachelor's Degree & 915 & 85.4 \\
\hline & Master's Degree or Higher & 156 & 14.6 \\
\hline \multirow{3}{*}{ Location of the School } & Province Center (urban) & 415 & 38.7 \\
\hline & County Center (semi urban) & 502 & 46.9 \\
\hline & Village (rural) & 154 & 14.4 \\
\hline \multirow{13}{*}{ Territorial Unit } & İstanbul & 200 & 18.7 \\
\hline & West Marmara & 47 & 4.4 \\
\hline & Aegean & 136 & 12.7 \\
\hline & East Marmara & 103 & 9.6 \\
\hline & West Anatolia & 104 & 9.7 \\
\hline & Mediterranean & 137 & 12.8 \\
\hline & Central Anatolia & 52 & 4.9 \\
\hline & West Black sea & 61 & 5.7 \\
\hline & East Black sea & 34 & 3.2 \\
\hline & Northeast Anatolia & 52 & 4.9 \\
\hline & Middle East Anatolia & 65 & 6.1 \\
\hline & Southeast Anatolia & 80 & 7.5 \\
\hline & Total & 1071 & 100 \\
\hline
\end{tabular}

\section{Data Collection Tool}

A questionnaire form consisting of 8 questions developed by the researchers was used for data collection. The first 6 multiple-choice questions aimed at determining the demographic information of the participant (gender, age, type of school worked at, highest education level attained, the location of the school and the territorial unit). The $7^{\text {th }}$ question aims to reveal what common situations negatively affected teachers' work in the distance education process. The studies in the relevant literature were availed for determining the factors that prevent teachers from performing distance education and therefore generating a list of troubling situations, consisting of $32 \mathrm{sub}$-items belonging to question 7 . Teachers were then asked to respond stating whether they agree or disagree with experiencing the troublesome situation explained in each of the 32 items. The final, 8th question was open-ended in nature and invited the teachers to share their opinions on how the current distance education system could be improved. For content validity of the data collection tool, opinions of 2 academics working in Computer Education and Information Technologies Teaching departments, 1 IT specialist working in Turkish Information and Communication Technologies Authority (ICTA) and 4 teachers from different fields of study working in public schools were received, and the scale was finalized. 


\section{Data Collection Process}

The data collection instrument was prepared on the website SurveyMonkey and access link was shared among teacher professional groups on Facebook and WhatsApp social networks between the dates of 30 March- 1 June 2020. Access to the scale was allowed only once from the same IP address. Participation was sought on a voluntary basis.

\section{Data Analysis}

Categorical data obtained from teachers by means of data collection tool, were analyzed by frequency analyses and chi-square tests; qualitative data were analyzed with content coding. SPSS 24 and NVIVO 10 software programs were used for quantitative and qualitative analyses, respectively.

\section{Findings}

\section{Problems Encountered During Distance Education Activities}

The first research question sought to find out the most common factors considered to affect teachers negatively during distance education in the pandemic period. Data required for answering this research question was obtained by teacher responses to each of the 32 sub-items found under the $7^{\text {th }}$ question in the Data Collection Tool. The frequency and percentage distribution of the answers of the teachers in the sample regarding whether they encountered the listed problems or not is presented in Table 3.

Table 3. Distribution of Problems Teachers Encounter During Distance Education Activities

\begin{tabular}{|c|c|c|c|c|}
\hline & \multicolumn{2}{|c|}{ Disagree } & \multicolumn{2}{|c|}{ Agree } \\
\hline & $\mathrm{f}$ & $\%$ & $\mathrm{f}$ & $\%$ \\
\hline Some of my students do not have a computer. & 80 & 7.5 & 991 & 92.5 \\
\hline Some of my students do not have an internet connection. & 115 & 10.7 & 956 & 89.3 \\
\hline My students have no distance education experience & 117 & 10.9 & 954 & 89.1 \\
\hline $\begin{array}{l}\text { Some of my students have trouble following courses because of computer } \\
\text { sharing, as they have other siblings going to school. }\end{array}$ & 246 & 23.0 & 825 & 77.0 \\
\hline My students are not interested in distance education. & 251 & 23.4 & 820 & 76.6 \\
\hline Parents seek support from me for their technical problems. & 260 & 24.3 & 811 & 75.7 \\
\hline Parents are not interested in/ do not take distance education seriously. & 303 & 28.3 & 768 & 71.7 \\
\hline The type of teaching materials in EBA/ ADES is insufficient. & 409 & 38.2 & 662 & 61.8 \\
\hline The number of teaching materials in EBA/ ADES is insufficient. & 422 & 39.4 & 649 & 60.6 \\
\hline $\begin{array}{l}\text { I have to set a password for students who cannot get a password for EBA } \\
\text { otherwise. }\end{array}$ & 431 & 40.2 & 640 & 59.8 \\
\hline I am having trouble reconnecting after disconnecting in EBA/ ADES. & 432 & 40.3 & 639 & 59.7 \\
\hline I cannot control student learning in live courses. & 440 & 41.1 & 631 & 58.9 \\
\hline $\begin{array}{l}\text { I rely on support from my colleagues for technical problems related to EBA/ } \\
\text { ADES, such as login, password retrieval or disconnection. }\end{array}$ & 453 & 42.3 & 618 & 57.7 \\
\hline I am having trouble connecting to EBA / ADES for the first time. & 499 & 46.6 & 572 & 53.4 \\
\hline $\begin{array}{l}\text { My students who do not have a computer do not know how to enter EBA/ ADES } \\
\text { from their smartphones. }\end{array}$ & 518 & 48.4 & 553 & 51.6 \\
\hline Visual and audio quality is poor in live courses. & 551 & 51.4 & 520 & 48.6 \\
\hline I cannot lecture due to the lack of student participation. & 567 & 52.9 & 504 & 47.1 \\
\hline $\begin{array}{l}\text { I cannot get support from the official ch } \\
\text { problems related to EBA/ ADES, st }\end{array}$ & 584 & 54.5 & 487 & 45.5 \\
\hline
\end{tabular}


I cannot get support from an official channel for technical problems with EBA / ADES, such as login, password retrieval or disconnection.

I cannot use the whiteboard application effectively due to technical problems.

$\begin{array}{llll}643 & 60.0 & 428 & 40.0\end{array}$

I experience frequent disconnection in EBA/ ADES.

$\begin{array}{llll}651 & 60.8 & 420 & 39.2\end{array}$

I do not have enough knowledge or experience of conducting live courses.

$\begin{array}{llll}694 & 64.8 & 377 & 35.2\end{array}$

My internet connection speed is low.

$\begin{array}{llll}701 & 65.5 & 370 & 34.5\end{array}$

I do not have enough knowledge or experience of distance education.

$\begin{array}{llll}728 & 68 & 343 & 32\end{array}$

The internet quota I use is insufficient, I have to buy additional data packages. $\quad \begin{array}{llll}752 & 70.2 & 319 & 29.8\end{array}$

The technical features of the computer I use (operating system, RAM, display and sound card etc.) are insufficient for EBA/ ADES applications.

$\begin{array}{llll}757 & 70.7 & 314 & 29.3\end{array}$

I do not have enough knowledge or experience to use EBA/ ADES.

$800 \quad 74.7 \quad 271 \quad 25.3$

I cannot screen share due to technical problems.

$835 \quad 78 \quad 236 \quad 22$

I do not know how to get a live course password.

$869 \quad 81.1 \quad 202 \quad 18.9$

The system is not detecting the microphone and/or speaker required for the live course.

$\begin{array}{llll}912 & 85.2 & 159 & 14.8\end{array}$

I cannot download the live course application.

$\begin{array}{llll}956 & 89.3 & 115 & 10.7\end{array}$

I have to? log in to EBA/ ADES with a different name.

$\begin{array}{llll}1031 & 96.3 & 40 & 3.7\end{array}$

\section{The Relationship of Problems Encountered During Distance Education Activities and Demographic Variables}

The second research question is related to whether teachers in various demographic groups have been affected differently by certain problems. In order to obtain an answer to this question, each of the categorical variables including, gender, age group (21-40 and 41+), school type (primary-secondary-high school), location (village, district and province) and educational status (bachelor's degree and master's degree or higher), were analyzed within the framework of the chi-square test, with each of the answers given as to whether the listed problems were encountered. The results of the chi-square test in which significant $\mathrm{p}$ values at the .05 level are presented, are marked in Table 4.

Table 4. The Association between Problems encountered During Distance Education Activities and Demographic Variables

\begin{tabular}{|c|c|c|c|c|c|}
\hline & $\begin{array}{l}\overline{0} \\
\overline{0} \\
0\end{array}$ & $\stackrel{80}{<}$ & 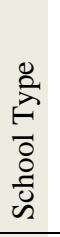 &  & 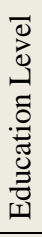 \\
\hline Some of my students do not have a computer. & & * & & $*$ & $*$ \\
\hline Some of my students do not have an internet connection. & & $*$ & & $*$ & \\
\hline My students have no distance education experience & & & & $*$ & \\
\hline $\begin{array}{l}\text { Some of my students have trouble following courses because of computer sharing, as they have other } \\
\text { siblings going to school. }\end{array}$ & & & & & \\
\hline My students are not interested in distance education. & & $*$ & $*$ & $*$ & $*$ \\
\hline Parents seek support from me for their technical problems. & & & $*$ & & \\
\hline Parents are not interested in/ do not take distance education seriously. & & $*$ & * & $*$ & \\
\hline The type of teaching materials in EBA/ ADES is insufficient. & & & * & & \\
\hline The number of teaching materials in EBA/ ADES is insufficient & & & * & & \\
\hline
\end{tabular}


I have to set a password for students who cannot get a password for EBA otherwise.

I am having trouble reconnecting after disconnecting in EBA/ ADES.

I cannot control student learning in live courses.

I rely on support from my colleagues for technical problems related to EBA/ ADES, such as login, password retrieval or disconnection.

I am having trouble connecting to EBA / ADES for the first time.

My students who do not have a computer do not know how to enter EBA/ ADES from their smartphones.

Visual and audio quality is poor in live courses.

I cannot lecture due to the lack of student participation.

I cannot get support from the official channel in a timely manner for technical problems related to EBA/ ADES, such as login, password retrieval or disconnection.

I cannot get support from an official channel for technical problems with EBA / ADES, such as login, password retrieval or disconnection.

I cannot use the whiteboard application effectively due to technical problems.

I experience frequent disconnection in EBA/ ADES.

I do not have enough knowledge and experience in doing live courses.

My internet connection speed is low.

I do not have enough knowledge and experience about distance education.

The internet quota I use is insufficient, I have to buy additional data packages.

The technical features of the computer I use (operating system, RAM, display and sound card etc.) are insufficient for EBA/ ADES applications.

I do not have enough knowledge and experience to use EBA/ ADES.

I cannot screen share due to technical problems.

I do not know how to get a live course password.

The system is not detecting the microphone and speaker required for the live course.

I cannot download the live course application.

I log in to EBA/ ADES with a different name.

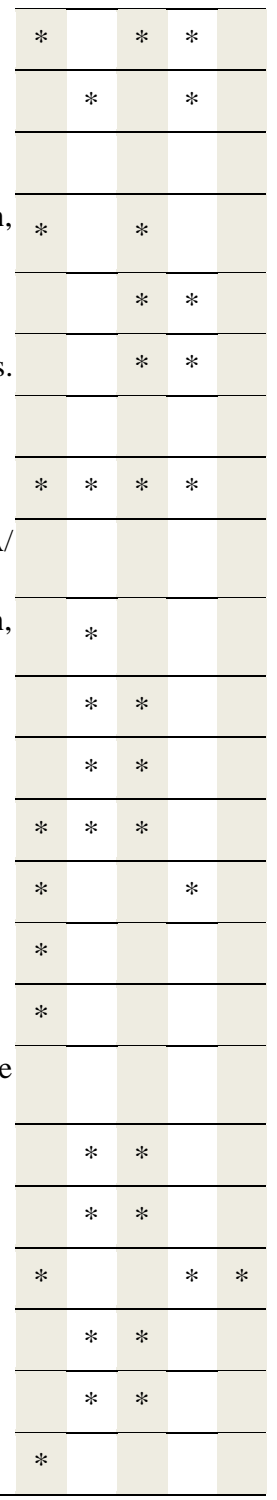

*. The Chi-square statistic is significant at the .05 level.

\section{Relationship Between Gender and The Problems Encountered During Distance Education Activities}

When the findings were analyzed according to gender variable, male teachers were found to be statistically significantly more prone to reporting the following problems compared to female teachers: Having to set a password for students who cannot get a password with egovernment $(\chi 2(1)=4.626, p<.05)$, Failure to perform lectures due to lack of student participation $(\chi 2(1)=14.674, p<.05)$, Low internet connection speed $(\chi 2(1)=14.210, p<.05)$, Having to buy additional data packages due to insufficient internet quota $(\chi 2(1)=5.236, p<.05)$, logging in EBA/ ADES with a different name $(\chi 2(1)=5.253, p<.05)$. Female teachers, on the other hand, were found to be statistically significantly more prone to reporting the following problems compared to male teachers: Relying on support from colleagues for technical problems related to EBA/ ADES, such as login, password retrieval or disconnection $(\chi 2(1)=$ $12.106, p<.05)$, Lack of knowledge and experience in performing live courses $(\chi 2(1)=5.952$, $p<.05)$, Lack of knowledge and experience in distance education $(\chi 2(1)=7.449, p<.05)$, Not knowing how to get a live course password $(\chi 2(1)=16.082, p<.05)$. 


\section{Relationship Between Age Group and The Problems Encountered During Distance Education Activities}

When the findings were analyzed according to age group variable, teachers in the age group of 21-40 were found to be statistically significantly more prone to reporting the following problems compared to teachers in the age group of 41+: some students' not having a computer $(\chi 2(1)=7.144, p<.05)$, some students' not having internet connection $(\chi 2(1)=15.733, p<.05)$, students' not being interested in distance education $(\chi 2(1)=11.166, p<.05)$, parents are not interested $\mathrm{in} /$ do not take distance education seriously $(\chi 2(1)=22.781, p<.05)$, failure to perform lectures due to lack of student participation $(\chi 2(1)=8.713, p<.05)$. Teachers in the age group of $41+$ on the other hand, were found to be statistically significantly more prone to reporting the following problems compared to younger colleagues: Having trouble reconnecting after disconnection in EBA/ ADES $(\chi 2(1)=7.945, p<.05)$, Not being able to get support from an official channel for technical problems such as logging in, getting password or disconnection related to EBA/ ADES $(\chi 2(1)=33.528, p<.05)$, Not being able to use the whiteboard application effectively due to technical problems $(\chi 2(1)=3.950, p<.05)$, Frequent disconnection in EBA / ADES $(\chi 2(1)=4.280, p<.05)$, Not having sufficient knowledge and experience in performing live courses $(\chi 2(1)=6.750, p<.05)$, Not having enough knowledge and experience to use EBA/ ADES $(\chi 2(1)=7.262, p<.05)$, Not being able to screen share due to technical issues $(\chi 2(1)=8.767, p<.05)$, Failure of the system to detect the microphone and speaker required for the live courses $(\chi 2(1)=5.665, p<.05)$, and not being able to download the live course application $(\chi 2(1)=7.373, p<.05)$.

\section{Relationship Between School Type and The Problems Encountered During Distance Education Activities}

According to the school type variable, it was observed that the following variables and school type were statistically significantly related and post-hoc tests have shown that these problems are more likely to be raised by teachers working at primary school level: (a) Thinking that the type of teaching materials in EBA/ ADES is insufficient $(\chi 2(2)=6.209, p<.05)$, (b) Thinking that the number of teaching materials in EBA/ ADES is insufficient $(\chi 2(2)=6.668$, $p<.05)$, (c) Having to set a password for students who cannot get a password for EBA otherwise $(\chi 2(2)=11.757, p<.05)$, (d) Having trouble connecting to EBA/ADES for the first time $(\chi 2(2)=11.572, p<.05)$, (e) Students who do not have a computer do not know how to $\log$ in EBA/ ADES from their smart phone $(\chi 2(2)=19.849, p<.05)$, (f) Not being able to use the whiteboard application effectively due to technical problems $(\chi 2(2)=10.777, p<.05),(\mathrm{g})$ Frequent disconnection in EBA/ADES $(\chi 2(2)=10.743, p<.05)$, (h) Not having sufficient knowledge and experience in conducting live courses $(\chi 2(2)=18.462, p<.05)$, (i) Not having enough knowledge of or experience in using EBA/ADES $(\chi 2(2)=11.771, p<.05)$, (j) Not being able to screen share due to technical issues $(\chi 2(2)=25.547, p<.05),(\mathrm{k})$ Failure of the system to detect the microphone and speaker required for the live courses $\left(\chi^{2}(2)=15.233, p<.05\right)$, (1) Inability to download the live course application $(\chi 2(2)=, p<.05)$. And, as a result of the analysis of post-hoc tests, it was observed that the following variables, which are significantly related to school type, are more likely to be expressed by teachers working at secondary school level: (a) students not being interested in distance education $(\chi 2(2)=40.930, p<.05)$, (b) parents not being interested in/ not taking distance education seriously $(\chi 2(2)=7.110, p<.05)$, (c) relying on support from colleagues for technical problems related to EBA/ADES, such as login, password retrieval or disconnection $(\chi 2(2)=6.536, p<.05)$. The variable of not being unable to perform lectures due to the lack of student participation $(\chi 2(2)=32.480, p<.05)$ was also found to be significantly related with school type and according to post-hoc tests, this points to a more 
likely problem since it is expressed by teachers at high school level. Finally; variables of parents seeking support from teachers for technical problems they experience $(\chi 2(2)=93.681, p<.05)$ and students without a computer not knowing how to log in EBA/ ADES from their smartphone $(\chi 2(2)=19.849, p<.05)$ were found to be significantly related with the type of school and as observed in post-hoc tests, and these are problems less likely to be expressed by teachers working at high school level.

\section{Relationship Between Location of The School and The Problems Encountered During Distance Education Activities}

An investigation of the school location variable has revealed that the following variables and school location were statistically significantly related and post-hoc tests have shown that these problems are more likely to be raised by teachers working in village schools (rural areas): (a) students not being interested in distance education $(\chi 2(2)=15.788, p<.05)$, (b) parents not being interested in/ not taking distance education seriously $(\chi 2(2)=29.189, p<.05)$, (c) students without a computer not knowing how to log in EBA/ ADES from their smartphones $(\chi 2(2)=22.880, p<.05)$, (d) failure to perform lectures due to lack of student participation $(\chi 2(2)=54.450, p<.05)$, and (e) not knowing how to get a live course password $(\chi 2(2)=7.655$, $p<.05)$. And, as a result of the analysis of the post-hoc tests, it was observed that the following variables, which are significantly related to the location of the school, are more likely to be expressed by teachers working in county centers (semi-urban areas): (a) students do not have distance education experience $(\chi 2(2)=7.776, p<.05)$, (b) Having trouble reconnecting after disconnection in EBA/ ADES $(\chi 2(2)=7.221, p<.05)$, (c) Having trouble connecting to EBA/ ADES for the first time $(\chi 2(2)=6.647, p<.05)$ and (d) low connection speed of the internet used $(\chi 2(2)=8.786, p<.05)$. It was also understood by post-hoc tests that the following variables, which are significantly related to the school location, are less frequently expressed by teachers working in provincial centers (urban areas); and more frequently expressed by teachers working in the county centers and villages: (a) some students' not having a computer $(\chi 2(2)=30.262$, $p<.05)$, (b) some students' not having an internet connection $(\chi 2(2)=28.847, p<.05)$ and (c) parents' not being interested in/ not taking distance education seriously $(\chi 2(2)=29.189, p<.05)$. Finally, it is a statistically significant result that teachers working in provincial centers (urban areas) tend to state the problem of having to set a password for students who cannot get a password for EBA otherwise more frequently than teachers in villages and country centers $(\chi 2(2)=8.284, p<.05)$.

\section{Relationship Between Education Level and The Problems Encountered During Distance Education Activities}

When the educational level of the participating teachers were analyzed, it was observed that teachers with a bachelor's degree were more prone to express the following problems compared to their colleagues with a master's or doctoral degree: some students' not having a computer $(\chi 2(2)=, p<.05)$, students' not being interested in distance education $(\chi 2(2)=, p<.05)$ and not knowing how to get live course password $(\chi 2(2)=, p<.05)$.

\section{Teachers' Views on Improving the Distance Education System and Increasing The Success}

269 out of 1071 teachers who participated in the study answered the $8^{\text {th }}$, open-ended question in the data collection instrument, which urged teachers to share their opinions on how to improve the current distance education system. Content coding was carried out on the 
answers and subsequent themes were determined. In order to establish the reliability of coding carried out by a single researcher; a subset of the data set with 50 answers was coded by 2 additional raters as described by Hallgren (2012). Finally, Cohen's Kappa inter-rater reliability coefficient between the three coders was found to be 0.54 , corresponding to moderate consistency (Kılıç, 2015; McHugh, 2012).

\section{General Expectations}

The answers were first examined in terms of the elements of education system the teachers expected interventions for improvement from. When their statements $(\mathrm{N}=230)$ implying implicitly or explicitly expectations from a certain element of the education system were examined, it has been observed that teachers predominantly expect intervention from higher administrative structures of public or private nature such as the Ministry of Education itself or Internet Service Providers and GSM Operators ( $\mathrm{N}=134,58 \%)$. This is followed by expectations from the EBA/ ADES system $(\mathrm{N}=63,27 \%)$; a small number of teachers were found to have expectations from student parents $(\mathrm{N}=14,6 \%)$, their colleagues $(\mathrm{N}=8,3 \%)$, their students $(\mathrm{N}=7,3 \%)$ and their school's administration $(\mathrm{N}=3,1 \%)$. When the implications $(\mathrm{N}=146)$ about who the desired educational interventions can benefit from were investigated, it was found that interventions that students can benefit from were most frequently requested $(\mathrm{N}=86 ; 59 \%)$, followed by interventions requests that would benefit teachers $(\mathrm{N}=40,27 \%)$ and parents $(\mathrm{N}=20,14 \%)$. Before moving on to their views about distance education or the EBA/ ADES systems, it was seen that in all teacher responses $(\mathrm{N}=269)$, the theme of problems regarding technical means of access to distance education $(\mathrm{N}=102,37 \%)$ was commonly encountered. It was observed that this theme consisted 62\% ( $=39)$ of emphases on internet access problems and 38\% ( $\mathrm{N}=39)$ of emphases on device access. Another theme frequently observed alongside the access problem theme and encountered in $21 \%(\mathrm{~N}=56)$ of all teachers' answers $(\mathrm{N}=269)$ was a request for financial aid, most commonly in the form of device or internet access provision. A theme encountered in $28 \%(\mathrm{~N}=75)$ of all answers $(\mathrm{N}=269)$ was requests for additional education interventions for facilitating distance education. $13 \%(\mathrm{~N}=10)$ of these requests were education requests in the context of technology literacy. Requests in this context made mention of who should be targeted by these additional educational interventions $(\mathrm{N}=63)$, wherein the names of parents $(\mathrm{N}=23,37 \%)$ and students $(\mathrm{N}=22,35 \%)$ were mentioned first. It was also stated that teachers should receive in-service training in various contexts $(\mathrm{N}=18,29 \%)$. Among all the listed expectations for the improvement of distance education $(\mathrm{N}=269)$, other prominent themes are a) an emphasis on rural regions $(\mathrm{N}=11,4 \%)$, and $\mathrm{b}) \mathrm{a}$ request for technical support or communication centers $(\mathrm{N}=5,2 \%)$.

\section{Expectations from the EBA and ADES Systems}

When statements directly related to EBA/ADES systems $(\mathrm{N}=95)$ were examined, it was seen that the subject most frequently referred to was platform content of EBA/ ADES ( $=37$, $39 \%$ ). In their statements about the content, it was seen that the teachers most frequently expressed unmet expectations in terms of the subject scope of content in EBA $(\mathrm{N}=22,60 \%)$ or expressed expectations in terms of content type or quality $(\mathrm{N}=12, \% 32)$. The second most common theme in statements related to EBA / ADES $(\mathrm{N}=95)$ is the technical problems specific to these systems $(\mathrm{N}=22,23 \%)$, and complaints about the inadequacies in terms of usability $(\mathrm{N}=14,15 \%)$. A striking theme encountered in the statements about EBA/ ADES was the references to alternative software products $(\mathrm{N}=12,13 \%)$, sometimes including recommendations on the use of different software products instead of EBA. 


\section{Views on the Distance Education Notion}

In the answers of the teachers, it was seen that they tended to express various views about the overall notion of distance education $(\mathrm{N}=98)$. The most common of these views are related to shortcomings of the existing Internet infrastructure that were realized during distance education $(\mathrm{N}=40,41 \%)$. Another common theme in the statements of the teachers $(\mathrm{N}=98)$ who presented their opinions about the notion of distance education was the emphasis on equity in public education $(\mathrm{N}=17 ; 17 \%)$. The theme of communication difficulties experienced during distance education has been observed in $7 \%$ of the teachers' statements expressing opinions about the overall notion of distance education $(\mathrm{N}=7)$ and $4 \%$ showcased the theme $(\mathrm{N}=4)$ that teachers should be supervised and sanctioned more strictly in order to fulfill their duties properly/as desired in the distance education process. Last but not least, a theme encountered in teacher responses was negative views on the general notion of distance education $(\mathrm{N}=12$, $12 \%)$.

\section{Views on Lecture Processes in Distance Education}

In the answers given by the teachers, it was observed that they shared their views and anecdotes about lecturing in distance education $(\mathrm{N}=119)$. When these statements were analyzed, it was seen that the most common theme was low student motivation and an associated decrease in student participation to distance education courses $(\mathrm{N}=39,33 \%)$. Another important theme that stands out among the views on lecturing in distance education $(\mathrm{N}=119)$ is a demand for richer content suitable for use in distance education lessons $(\mathrm{N}=28$, $24 \%)$ and the need for parent support $(\mathrm{N}=21,18 \%)$. Finally, some teachers expressed their feelings about the necessity of requiring class attendance in order to increase student participation while expressing their opinions about lecturing $(\mathrm{N}=6,5 \%)$.

\section{Miscellaneous}

A theme encountered in $6 \%$ of all answers $(\mathrm{N}=17)$ manifests itself as references to assessment and evaluation processes. 59\% of these $(\mathrm{N}=10)$ mention the need for grading and class failure systems to be implemented whereas $35 \%(\mathrm{~N}=6)$ refer to the online exam concept. Again, in a theme found in $2 \%$ of all answers $(\mathrm{N}=6)$, it is seen that the teachers addressed the notion in terms of its psychological dimensions.

\section{Discussion and Conclusion}

COVID-19 pandemic has had a negative impact on life across the world in many aspects. This study examines the situation from the Turkish perspective and investigates the nationwide experiences of in-service K12 teachers during the transition to emergency remote education.

It has been observed that limitations in device and Internet connection access, alongside infrastructural shortcomings are the situations most commonly referred to by in-service teachers as they describe with their own words the problems encountered by children, especially those living in rural areas, during emergency remote education. In the early days of the pandemic all stakeholders of education have been caught off guard and it may be expected that some students experienced such problems. However, according to the data obtained from Turkish Statistical Institute (Turkstat) based on the Survey on Information and Communication Technology (ICT) Usage in Households in 2020, the ratio of the individuals using the Internet in Turkey was $79 \%$. Among the individuals included in the survey in question, $16.7 \%$ reported to having a personal computer, $36.4 \%$ had netbook/notebooks, $22 \%$ had a tablet and $99.4 \%$ had a smartphone (Turkish Statistical Institute, 2020). The fact that the complaints, which are 
commonly expressed in terms of problems in computer and internet access, are inconsistent with the statistics of Turkstat can be attributed to the collection of data only from individuals between the ages of 16-74 in that survey. It should also be noted that individuals' use of these technologies for educational purposes is not accounted for in Turkstat's analysis. In any case, it should be noted that there may be discrepancies between the computer and raw internet usage statistics and the access to distance education statistics of a country.

The findings pertaining to the inability of students, especially those in rural areas, to have access to computers and the internet is a common problem observed by teachers in this study. These are parallel to the results showcased by Korkmaz and Toraman (2020), who report an internet access problem experienced by students during the pandemic period. In the study conducted by Koçoğlu (2020), 33\% of the teachers considered the lack of technological infrastructure as an obstacle to distance education. $20 \%$ of teachers who participated in the same study stated that distance education activities during the pandemic period differed among various regions of the country and that these differences were mainly caused by differences in economic and technological infrastructure. Doğan and Koçak (2020) list the most important problems encountered during emergency remote education as the lack of access to internet connection and electronic devices for all students. Basaran et al. (2020) also emphasize the notion of unequal opportunity in distance education and list recommendations to improve the situation in their study. In a study carried out by Sarı and Nayır (2020) in which the education reports published by UNESCO, OECD and World Bank in 2020 were evaluated, emphasis has been placed on unequal opportunity in accessing education being amongst the most prominent factors that cause disruption of education during the pandemic period. Code et al, 2020; Doghonadze et al., 2020; Klapproth et al., 2020; Nalaskowski, 2020; Noor et al., 2020; Shraim and Crompton, 2020 and Xie et al., 2020 also argued that limited access to internet and computers by teachers and students and insufficient internet bandwidth are obstacles to adequate distance education.

There have been other recent studies that refer to teacher opinions for defining problems underlying emergency remote education. For instance, a study conducted by Bayram (2021) also referred to the opinions of elementary school teachers on the shortcomings of emergency remote education during pandemic and listed the most prominent problems to be a) existence of students that lack access computers or tablets, b) the lack of digital literacy in students causing failure to operate EBA, c) internet connection problems or an entire lack of internet infrastructure in rural areas. The same study also reports lack of student motivation, low participation rates and the difficulty of classroom management in online courses are detrimental to quality of emergency remote education. Other international studies have also included teachers working in K12 and discussed the ways through which they thought distance education could be improved, arriving at the conclusion that teachers most prominently refer to access problems including those reported by children who have to share connection or device with their siblings where both are students, which lead to lack of motivation and a greater portrait of unequal opportunity (Cardullo, Wang, Burton \& Dong, 2021; Trust \& Whalen, 2021).

Teachers participating in this study have most frequently hinted at the provision of financial aid to students in the form of device and internet access provision as a means to solve these problems. As it is also addressed in the studies of Corlatean (2020) and Sar1 and Nayır (2020), increased education costs (computer, tablet, smartphone, internet, internet package, electricity, etc.) are important as they disrupt distance education, a situation which supports the idea specified above. Among the recommendations provided by the teachers prioritizing the development of infrastructure and provision of auxiliary resources such as mobile libraries to 
students where necessary, can be mentioned. In order to rapidly solve the technical problems encountered by students and parents in the distance education processes, establishing an Information Provision Center or providing remote assistance support by digitally connecting to student devices, are among the other expectations and recommendations of teachers.

Furthermore, they draw attention to the educational requirements of parents, students and teachers and underline the importance of the provision of internet, computer and distance education literacy skills. Cardullo, Wang, Burton and Dong (2021) have also reported similar results in their study stating that K12 teachers have been caught unprepared for emergency remote education due to a lack of both distance education experience and computer literacy. Jacques and Shrubb (2020) also highlight the fact that almost all schools up until the pandemic had been providing nothing but face-to-face education and thus had no prior experience or action plan that is pertinent to distance education resulting in problems in educational planning and execution during remote education. Sezgin (2021) showcases a comprehensive review of 152 studies on emergency remote education during pandemic days, emphasizing the technopedagogical shortcomings of teachers to be among the primary reason for problems. Klapproth et al. (2020), Korkmaz and Toraman (2020) and Noor et al. (2020) therefore suggest that training is necessary in order to improve the distance education competencies of teachers and their skills in using IT and learning management systems. All in all, the pandemic has proven that distance education, along with its sophisticated software and hardware requirements, will remain as an important element of public education even after the end of this period of crisis. For this reason, professional competencies of teachers need to be bolstered with training programs for digital literacy as well instructional technology (Balas, 2020).

The lack of distance education experience of students in K12 is another prominent problem mentioned by the teachers. The main reason for this situation may be the fact that widespread implementations of distance education or hybrid educational models had not been tested in Turkish schools up until the pandemic. Therefore, the lack of experience also of students might have been evaluated as an issue by the teachers in the present study .

What teachers have stated frequently is the decrease in the attendance rate of students, which may also be explained with the students' being accustomed to face-to-face education and feeling alienated with remote education mostly due to lack of experience. Indeed, the lack of course attendance, the lack of sanctions for eliminating this problem, and low student motivation for attending online classes have all been frequently pronounced by the participant teachers in the current study. There are similar studies in the literature reporting that low attendance of students is expressed as a problem in the distance education process (Alvarez, 2020; Bakioğlu and Çevik, 2020; Başaran et al., 2020; Bayburtlu, 2020; Code et al., 2020; Klapproth et al., 2020; Nalaskowski, 2020; Nambiar, 2020; Noor et al., 2020; Shraim and Crompton, 2020). A study by Demir and Demir (2021) on the opinions of parents on the state of the emergency remote education in Turkey illustrate that, more than half of the study participants report a drop in their children's course motivation due to problems of technical nature; whereas half of the participants mention a loss in motivation due to "cabin fever" experienced by children under lockdown. Under such detrimental conditions, the importance of high self-discipline as a factor for effective distance education is once again understood. For this skill to be internalized by the students, teachers need to know how to encourage and motivate them effectively (Xie et al., 2020). The lack of student motivation and course attendance may also be due to the fact parents' not being interested in distance education in the first place, as reported by teachers in this study. Parents' being unconcerned with distance education may, at times, be due to the lack of sufficient knowledge and skills about internet and computer use and distance education. the involvement of one or both parents in the professional 
life can occasionally cause the parents to 'seem' unconcerned. This finding is parallel to the research findings of Bayburtlu (2020), Can and Köroğlu (2020) and Fidan (2020). A study by Aydin and Erol (2021) with Turkish language teachers in K12 also report low attendance rates of students and attribute this situation directly to indifference of parents. One study that explains the possible reason behind this situation, puts forward how a) parents with higher economic status display better skills in supporting the learning of their children in digital educational settings, b) lack of adult supervision in such settings may lead to academic or motivational failure in children (Amram \& Davidovitch, 2021; Dubois, Bright and Salimah, 2021). It can therefore be said that children of families with lower income levels or families where adults are constantly preoccupied may be more prone to experiencing difficulties in remote education. However, Demir and Demir (2021) put forth in their study that more than half of the participating Turkish parents are concerned and attentive with their children's remote education process, with almost all participating parents reporting ensuring supervision for their children during the course of education. Nevertheless, increasing the course hours and the number of? online exams, bringing a grading system to the agenda, taking attendance records of students, informing parents better about the necessity of distance education (Bayburtlu, 2020) and providing psychological support to all stakeholders (Kinard and Mahaffey, 2020; Sar1 and Nayır, 2020), are included in the recommendations of teachers as solution proposals addressing lack of motivation and course attendance.

Communication problems experienced with students have also been expressed by teachers in this study, to a relatively lower extent though. This finding coincides with the findings obtained from the studies of Alper (2020), Bakioğlu and Çevik (2020), Korkmaz and Toraman (2020) and Sarı and Nayır (2020). Trust and Whalen's (2021) recent study also reports that the most important problem encountered by teachers during emergency remote education is the set of difficulties in communication with students and families in the process. Another finding from outside the world of K12 education has been reported by Alawamleh, Al-Twait and Al-Saht (2020) who have worked with undergraduate students discovered these learners have a difficult time whilst communicating with their college instructors during remote education, which leads to a loss in their motivation. In his Transactional Learning Theory, Moore (1997) states that reciprocal communication between learner and instructor is vital for learning problems in the context of distance education. It has also been emphasized that the quality, as well as the frequency of communication, matters. Holmberg (1989) also mentioned the importance of learner-teacher interaction in improving learner motivation, through his Interaction and Communication Theory.

Teachers participating in this study have also explained the ways through which EBA/ADES platforms could be improved. Among these, the insufficiency of the current course materials and activities in EBA/ADES platforms, both in quality and quantity, was the most prominent. Similarly, the problem of insufficiency in resource diversity on EBA/ADES was also expressed by teachers in the study of Koçoğlu (2020). It is believed that the development of course materials that will attract the attention of students, motivate them, and ensure learning is entertaining as well as permanent, may be possible with the inclusion of novel technologies (such as Augmented Reality or Virtual Reality) in distance education (Shraim and Crompton, 2020). The creation of free course material pools, which can collectively be resorted to , also stands out among the recommendations of the teachers in this research. It has been observed that inability to use peripheral equipment and application required for video conferencing based live courses and EBA/ ADES login problems are among the least frequently mentioned problems. Based on these findings, it can be argued that teachers did not have much difficulty in using the peripheral equipment and software required for live courses in distance education. 
However, when the frequency of the problems reported regarding the EBA/ ADES platform is examined in general, it is found that problems such as content type and quantity are considered more important than system availability and technical issues. At this point, it is understood that the challenging aspects of emergency remote education in Turkey example have been a) to make sure that students have the necessary facilities to access this service, $b$ ) to ensure that the content in the said service is rich and interesting.

Few of the teachers who participated in the study and working in non-profit public schools stated that some of their colleagues were not active enough in their courses, and that not all teachers spent the same amount of effort in distance education. It is implied that no sanctions were applied to deter teachers from poor job performance in this regard. It was stated that the control and enforcement rules should be determined and implemented for teachers to conduct the classes in order to solve this problem. In a study carried out by Alper (2020) with teachers working at for-profit private school, it was found that many of the teachers qualified themselves and their peers to be effective and efficient in this process. This difference may be specific to for-profit private schools, which have significantly increased their share in the public education system in Turkey within the last decade, having enjoyed the freedom of implementing unique practices in distance education process such as the choice of teaching platform, development of course materials, assessment-evaluation practices, and the creation of teacher-student-parent communication channels independently, without having to resort to applications mandated by the Ministry of National Education. In addition, mechanisms of control may be applied more easily on teachers working in Turkish for-profit private schools due to employment concerns, as they work under annual contracts as opposed to their peers in public schools enjoying the status of public servant/tenure roles. It can therefore be argued that results indicating the ability of private school teachers to work more actively in the distance education process is not out of the ordinary. But factors that lead to poor performance of teachers in non-profit public schools during the pandemic period also need to be analyzed. Shraim and Crompton (2020) related this situation to the inadequate level of IT skills of teachers. The inability of some of the teachers to be involved in the process effectively and efficiently may have been caused by a negative perspective on distance education, the lack of knowledge, skills, hardware and software for distance education, the inconvenience of the teaching environment, or the psychological trauma and distractions caused by the pandemic.

Again, another argument encountered, although again to a lower extent, has revealed certain adverse opinions such as the inexpediency of distance education and the inability of distance education to compensate for the face-to-face educational activities. As Sar1 and Nayır (2020) have stated in their review of education reports, the pandemic may have paved the way for the teachers and instructors to attain a new perception of education within the Covid-19 process. Conversely, it has been identified in the study of Moçoşoğlu and Kaya (2020) that the attitudes of the teachers and instructors towards distance education remain at negative levels, whereas in the study of Nambiar (2020), teachers and instructors have expressed that distance education has both positive and negative aspects. In the study of Alea et al. (2020), 99\% of the teachers and instructors have stated that they are readily available in the event that remote education is initiated in case of an urgent and conclusory circumstance. Majority of the teachers and instructors have expressed in the study of Khalif et al. (2020) that they were not prepared upon the initiation of the distance education process and they have experienced a great variety of ambiguity related to the process. This situation, experienced by the majority of the teachers and instructors during the onset period of the pandemic, may have led to an adverse perspective towards distance education embraced by certain teachers and instructors. Inter alia, demographic attributes of teachers and instructors, Internet access facilities thereof, distance 
education experience history thereof, sufficiency of academic/technical/financial/psychological support of their affiliated educational institutions, convenience of lecturing environment at home can be listed among reasons of the discrepancy among these results in the literature.

When the associations between commonly encountered problems and teacher demographic data are examined, it was found that the gender of the teachers caused a statistically significant difference in terms of the problems encountered during distance education activities. Accordingly, problems encountered by female teachers in this process may be interpreted to rely more on personal inefficacy in information technology use, while problems faced by male teachers are more likely to arise from the inadequacies caused by external factors. In the literature, there are studies arguing that IT usage competencies are in favor of male teachers, which is consistent with this finding (Aktürk and Delen, 2020; Gülcü, Solak, Aydın and Koçak, 2013; Hacısalihoğlu, 2008; Menzi, Çalışkan and Çetin, 2012; Sengir, 2019; Sırakaya, 2019; Y1lmaz, 2012).

As with gender, different age groups have links to different types of problems. Analysis of age groups divided in a manner to include generations of $\mathrm{X}$ and $\mathrm{Y}$, revealed that the most common problems encountered by the teachers of $\mathrm{Y}$ generation in emergency remote education processes are related to students and their parents. On the contrary, the most common problems experienced by the teachers of $\mathrm{X}$ generation are the problems related to the use of hardware and software required for distance education and the inability to intervene in technical problems, due to the personal lack of knowledge and experience. Inclusion of generation $Y$ teachers in the digital native and generation $X$ teachers in the digital immigrant classification (Prensky, 2009) supports this finding. It can be argued that especially teachers of generation $\mathrm{X}$ require training in educational technologies and distance education literacy based on this finding. In the study of Khalif and colleagues (2020), teachers belonging to generation X report experiencing feelings of unpreparedness, incompetency and ambiguity in the context of distance education, which led to a negative disposition towards the concept.

In the analysis conducted to determine the relationship between the types of schools that teachers work in and the problems they encounter it has been observed that teachers working at upper levels such as secondary school and high school underline the problem of lack of student participation more frequently. This situation can be attributed to the fact that younger students are more likely to participate in the distance education process along with/under the supervision of a parent or a family member. Doghonadze et al. (2020) also argue that children who are raised and looked after by their grandparents instead of their parents may be more unconcerned and irresponsible in the distance education process, The issue of arental supervision may not be concerning parents of students at secondary and high school levels, and the decrease in the rate of participation in courses may also be due to reasons such as the presence of a dependent family member or the requirement to seek gainful employment as age progresses (Xie et al., 2020). It should be noted that teachers working at the primary school level, where participation is higher, are also more likely to find the materials on EBA/ADES platforms inadequate in quality and quantity.

An analysis of problems based on school location has revealed that the problem of lack of access to computers and the Internet was expressed more by the teachers working in village schools as opposed to more urbanized areas. In other words, the rate of internet and computer availability of students increase in the urban centers compared to rural areas. The finding of students' and parents' in rural areas being less interested in distance education, alongside the aforementioned finding, can be explained by the difference in economic, educational, social 
and cultural competence levels among families living in urban and rural areas. Khalif et al. (2020) also state that families with higher socio-economic levels are both more concerned about their children's education and are capable of spending more to access quality education. They also accentuate that the children of such families are less affected by the closure of schools compared to their peers.

In the last phase of the research, analysis was conducted on the teachers' opinions on improving the current distance education system in Turkey. It was understood that the expectations of the teachers came predominantly in the form of intervention requests from higher public or private administrative structures such as Ministry of Education or GSM operators. This is followed by expectations for the EBA/ADES system. Among the miscellaneous recommendations of teachers, has been the notion of using alternative platforms and communication applications with the rationale of overcoming technical or infrastructure-related problems experienced by teachers in accessing EBA/ADES platforms. Since the beginning of the pandemic and until today, EBA and ADES platforms and the ZOOM video conferencing suite have been integrated with one another and used in educational institutions affiliated to the Ministry of National Education for sharing course materials, live courses and interactive activities. It can be argued that problems experienced in some regions such as internet speed/ quota/access, problems in connection to EBA/ADES and difficulties due to lack of usability of the platform and its associated applications; as well as crowded classroom sizes have caused teachers to make this suggestion.

In the final analysis, it should be noted that despite an increase in device ownership and Internet access rates development of the Internet infrastructure and the minimization of the Digital Divide are prominent topics in the agenda of each country in the world. However, the decisions and actions taken on these issues are affected primarily by economic restraints to the greatest extent. Knee-jerk reactions by government authorities manifesting in the form of tablet or computer distribution need to be evaluated within the context of sustainability and in retrospect, scrutinizing the fate of past projects such as One Laptop Per Child. The reality of income disparity between the urban-rural areas or between social classes and infrastructure have once again come to the fore with the emergency remote education processes conducted during the pandemic process, and the issue of equal opportunity in education has been brought to agenda once again. However, all this should not mean that distance education is a lost cause. Therefore, as a result of this study it may be recommended that even in the near future when the pandemic conditions shall come to an end, it may be necessary to proceed with design efforts of education systems, where all elements are aligned to the distance education processes. Intensification of hybrid distance education models in formal education shall be a substantial step in this context. The software products to be utilized within the processes of distance education and the the relevant content shall therefore be improved in both qualitative and quantitative terms through these efforts. The findings of the study further reveal that the teachers, instructors, students and their parents are required to be supported by additional educational and training activities (IT use, Internet, distance education, web 2.0 applications, safe Internet use, and alike.). Finally, it should be noted that the average time spent by Turkish Internet users on the Internet is above the world average according to the January 2021 report We Are Social Digital Age (We Are Social, 2021). In consideration of the fact that distance education further increases the use of digital devices and the time spent on the Internet, it could be avowable that the students, teachers, instructors and parents are required to be supported in psychological terms within the scope of the hybrid educational ventures[A5] to be executed in the upcoming days. 


\section{References}

Aktürk, A. O.and Delen, A. (2020). The relationship between teachers' technology acceptance levels and self efficacy beliefs. Science, Education, Art and Technology Journal (SEAT Journal), 4(2), 67-80.

Alawamleh, M., Al-Twait, L., \& Al-Saht, G. R. (2020). The effect of online learning on communication between instructors and students during Covid-19 pandemic. Asian Education Development and Studies, Retrieved from https://www. emerald.com/insight/2046-3162.htm

Alea, L. A., Fabrea, M. F., Roldan, R. D. A., \& Farooqi, A. Z. (2020). Teachers' covid-19 awareness, distance learning education experiences and perceptions towards institutional readiness and challenges. International Journal of Learning, Teaching and Educational Research, 19(6),127-144. https://doi.org/10.26803/ijlter.19.6.8

Alper, A. (2020). K-12 distance education in the pandemic process: a case study. Millî Eğitim Dergisi, 49(1), Special Issue/2020, 45-67.

Alvarez, A. J. (2020). The phenomenon of learning at a distance through emergency remote teaching amidst the pandemic crisis. Asian Journal of Distance Education, 15(1), $127-$ 143.

Amram, M. B. and Davidovitch, N. (2021). Teachers attitudes towards e-teaching during covid19. Laplage em Revista (International), 7(2), May- Aug. 2021,13-32. Retrieved from https://www.researchgate.net/publication/348611260_Teachers\%27_attitudes_towards _e-teaching_during_COVID-19.

An, Y., Kaplan-Rakowski, R., Yang, J., Conan, J., Kinard W., \& Daughrity, L. (2020). Examining k-12 teachers' feelings, experiences, and perspectives regarding online teaching during the early stage of the covid-19 pandemic. Retrieved from https://widadkinard.com/scholarly-writing

Aydın, E. and Erol, S. (2021). The views of turkish language teachers on distance education and digital literacy during covid-19 pandemic. International Journal of Education \& Literacy Studies, 9(1), 60-71. Retrieved from http://dx.doi.org/10.7575/aiac.ijels.v.9n.1p.60

Bakioğlu, B. and Çevik, M. (2020). Science Teachers' Views on Distance Education in the COVID-19 Pandemic Process. Turkish Studies, 15(4), 109-129. https://dx.doi.org/10.7827/TurkishStudies.43502

Bayburtlu, Y. S. (2020). Turkish Education During Covid-19 Pandemic Distance Education Process. Turkish $\quad$ Studies, 13(4), 151. https://dx.doi.org/10.7827/TurkishStudies.44460

Başaran, M., Doğan, E., Karaoğlu, E., \& Şahin, E. (2020). A study on effectiveness of distance education, as a return of Coronavirus (COVID-19) pandemic process. Academia Journal of Educational Research, 5(2), 368-397.

Bayram, H. (2021). Challenges secondary school teachers face during the distance education process. International Journal of Eurasian Education and Culture, 6(12), 613-658. Retrieved from https://www.ijoeec.com/DergiTamDetay.aspx?ID=306\&Detay=Ozet

Boz, S. M. (2016). Eğitimde Fatih Projesi ve EBA Tanıtım Faaliyetleri Değerlendirme Raporu. [A Report on the Evaluation of FATIH Project and EBA Promotional Activities] Innovation and Educational Technologies General Directorate 2016. Retrieved from https://yegitek.meb.gov.tr/meb_iys_dosyalar/2018_11/06104240_2016

_Serpil_BOz.pdf 
Can, N. and Köroğlu, Y. (2020). Evaluation Of Distance Education Escalating During COVID19 and Its Investigation From The Perspective Of Education Laborers. Madde, Diyalektik ve Toplum, 3(4), 370-380. Retrieved from https://bilimveaydinlanma.org/content/images/pdf/mdt/mdtc3s4/covid-19-donemindeyayginlasan-uzaktan-egitimin-degerlendirilmesi-ve-egitim-emekcileri-acisindanincelenmesi.pdf

Cardullo, V., Wang, C., Burton, M., \& Dong, J. (2021). K-12 teachers' remote teaching self-efficacy during the pandemic. Journal of Research in Innovative Teaching \& Learning, 4(1), 32-45. Retrieved from https://www.emerald.com/insight/23977604.htm

Casares, J. E. (2020). Public Education's Response to the Coronavirus (COVID-19) Pandemic. Retrieved from https://www.ncsl.org/research/education/public-education-response-tocoronavirus-covid-19.aspx

Code, J., Ralph, R., \& Forde, K. (2020). Pandemic designs for the future: perspectives of technology education teachers during covid-19. Information and Learning Sciences, 121(5/6), 419-443. DOI: 10.1108/ILS-04-2020-0112

Corlatean, T. (2020). Risks, discrimination and opportunities for education during the times of COVID-19 pandemic. In Proceedings of the 17th Research Association for Interdisciplinary Studies Conference (pp. 1-2).

Çifçi, F. and Demir, A. (2020). The effect of home-based exercise on anxiety and mental wellbeing levels of teachers and pre-service teachers in COVID-19 pandemic. African Educational Research Journal, 8(2), 20-28.

Davis, C. R., Grooms, J., Ortega, A., Rubalcaba, J. A. A., \& Vargas, E. (2021). Distance learning and parental mental health during COVID-19. Educational Researcher, 50(1), 61-64. https://doi.org/10.3102/0013189X20978806

Demir, E. and Demir, C. G. (2021). Investigation of parents' opinions about distance education during the covid-19 pandemic. Turkish Online Journal of Distance Education, April 2021, 22(2), Article 3. DOI:10.17718/tojde.906485

Directorate of Educational Innovation and Technology (2020). EBA tüm öğrencilerin 7/24 kullanımına açıldı. [EBA has been made available 24/7 for all students] Retrieved from https://yegitek.meb.gov.tr/www/eba-tum-ogrencilerin-724-kullaniminaacildi/icerik/3063

Doğan, S. and Koçak, E. (2020). A study on distance learning activities in the context of the eba system. Journal of Economics and Social Research, (14), 110-124. Retrievd from https://www.ekosad.net/FileUpload/ep939088/File/42_soner_dogan.pdf

Doghonadze, N., Aliyev, A., Halawachy, H., Knodel, L., \& Adedoyin, A. S. (2020). The degree of readiness to total distance learning in the face of covid-19 - teachers' view (case of Azerbaijan, Georgia, Iraq, Nigeria, UK and Ukraine). Journal of Education in Black Sea Region, 5(2), 2-41. DOI: 10.31578/jebs.v5i2.197

Dubois, E., Bright, D., \& Salimah, L. (2021). Educating minoritized students in the united states during covid-19: how technology can be both the problem and the solution. IEEE Computer Society, March/April 2021, 12-18. DOI: 10.1109/MITP.2021.3062765

EBA (2021a). EBA Tv Ders Yayını Nasıl Olacak. [How will the Eba Tv Educational Broadcast be] Retrieved from https://eba.gov.tr/\#/nasil-tv

EBA (2021b). EBA Akademik Destek. [EBA Academic Support] Retrieved from https://ders.eba.gov.tr/yardim-sss/ 
Fidan, M. (2020). Education in the uncertainty of COVID-19: Teachers' views on emergency remote teaching in primary school. Usak University Journal of Educational Research, 6(2). 24-43.

Fraenkel, J. R., \& Wallen, N. E. (2006). How to design and evaluate research in education (6th ed.). New York, NY: McGraw-Hill.

Gülcü, A., Solak, M., Aydın, S., \& Koçak, Ö. (2013). Opinions about using technologie in educations of branch teachers working at primary schools. International Periodical For The Languages, Literature and History of Turkish or Turkic, 8(6),195-213.

Gürbüz, B. (2018). İstatistik (Evren ve Örneklem). [Statistics (Universe and Samples)] Ankara University Repository of Open Courseware. Retrieved from https://acikders.ankara.edu.tr/pluginfile.php/105487/mod_resource/content/1/ders\%20 9\%20evren\%20ve\%20orneklem\%202.pdf

Hacisalihoğlu, H. (2008). The level of educational techniques used by teachers working at vocational commercial high schools. Unpublished Master's Thesis, Marmara University, Turkey.

Holmberg, B. (1989). Theory and practice of distance education. 2nd ed. London: Routledge.

Hürriyet (19.3.2020). Öğrencilere ücretsiz internet nasıl alınır?. [How to obtain free bandwidth for students] Retrieved from https://www.hurriyet.com.tr/galeri-ogrencilere-ucretsizinternet-nasil-alinir-eba-turk-telekom-vodafone-turkcell-ucretsiz-internet-kampanyasibasvurusu-41472356/5

ILO (2020). ILO Sectoral Brief. COVID-19 and the Education Sector. Retrieved from https://www.ilo.org/wcmsp5/groups/public/---europe/---ro-geneva/---iloankara/documents/briefingnote/wcms_742726.pdf

Jacques, L. A. \& Shrubb, R. G. (2020). PK-12 educators' requests for teaching during a pandemic. Proceedings of EdMedia Innovate Learning 2020 Conference, 56-60. Retrieved from https://researchgate.net/publication/344073480_PK12_Educators\%27_Requests_for_Teaching_during_a_Pandemic_Historical_Preparati on_for_Emergencies_in_K-12_Schools

Jalli, N. (2020). Lack of internet access in Southeast Asia poses challenges for students to study online amid COVID-19 pandemic. Retrieved from https://theconversation.com/lack-ofinternet-access-in-southeast-asia-poses-challenges-for-students-to-study-online-amidcovid-19-pandemic-133787

Karakaya, İ. (2012). Bilimsel araştırma yöntemleri. [Scientific Research Methods] A. Tanrı̈̈̆gen (Edt.) Bilimsel araştırma yöntemleri. Ankara: Anı.

Karasar, N. (1998). Araştırmalarda rapor hazırlama yöntemi.[Methods on preparing research reports] Ankara: Pars Matbaacılık Sanayi.

Khlaif, Z. N., Salha, S., Affouneh, S., Rashed, H., \& El Kimishy, L. A. (2020). The COVID19 epidemic: teachers' responses to school closure in developing countries, Technology, Pedagogy and Education, DOI: 10.1080/1475939X.2020.1851752

Kılıç, S. (2013). Örnekleme yöntemleri. [Sampling Techniques] Journal of Mood Disorders, 3(1), 44-46. DOI: 10.5455/jmood.20130325011730

Klapproth, F., Federkeil, L., Heinschke, F., \& Jungmann, T. (2020). Teachers' experiences of stress and their coping strategies during covid-19 induced distance teaching. Journal of Pedagogical Research, 4(4), $444-452$.

Kennette, L. and Chapman, M. (2021). Providing positive student feedback in an online environment. Academia Letters, Article 203, 1-3. https://doi.org/10.20935/AL203.

Kinard, W. and Mahaffey, F. D. (2020). Effects of covid-19 remote teaching on technology use and emotional needs of teachers. Retrieved from https://widadkinard.com/scholarlywriting 
Kiptala, W. and Kipruto, J. (2020). Covid 19 and teacher preparedness perception; challenges and opportunities, among teachers of secondary schools in baringo county, Kenya. World Journal of Innovative Research (WJIR), 9(5), 153-160.

Koçoğlu, E., Ulu Kalın, Ö., Tekdal, D., \& Yiğen, V. (2020). Covid-19 pandemi sürecinde Türkiye'deki eğitime bakış, [A Glance upon education in Turkey over the course of Covid-19 pandemic] International Social Sciences Studies Journal, 6(65), 2956-2966.

Korkmaz, G. and Toraman, Ç. (2020). Are we ready for the post-covid-19 educational practice? An investigation into what educators think as to online learning. International Journal of Technology in Education and Science (IJTES), 4(4), 293-309.

Levina, M. (2020). Central Asia countries switch to remote learning amid COVID-19 outbreak. Retrieved from https://www.timesca.com/index.php/news/26-opinion-head/22322central-asia-countries-switch-to-remote-learning-amid-covid-19-outbreak

Lindner, J., Clemons, C., Thoron, A., \& Lindner, N. (2020). Remote instruction and distance education: A response to Covid-19. Advancements in Agricultural Development, 1(2), 53-64.

Lionarakis, A., Orphanoudakis, T., Kokkos, A., Emvalotis, A., Manousou, E., Hartofylaka, A., Ioakimidou, V., Papadimitriou, S., Karagianni, E., Grammenos, N., Karachristos, C., \& Stavropoulos, E. (2020). The development of a massive online course on distance education to support greek school teachers during the covid-19 lockdown. Proceedings of ICERI2020 Conference, 9th-10th November 2020, Los Angeles, USA. Retrieved from https://iated.org/iceri/publications

Macvicar, A. (2020). Calgary school boards transition to online learning during COVID-19 pandemic. Retrieved from https://globalnews.ca/news/6754671/calgary-school-boardstransition-online-learning-covid-19-pandemic-coronavirus/

MebHaberleri (2020). Tüm öğrenci, veli ve öğretmenlere ücretsiz internet. [Free Internet for all students, their parents and teachers] Retrieved from https://www.mebhaberleri.com/tum-ogrenci-veli-ve-ogretmenlere-ucretsizinternet/1349/

Menzi, N., Çalışkan, E., \& Çetin, O. (2012). Examination of the Competencies of Pre-Service Teachers in Terms of Some Variables. Anadolu Journal of Educational Sciences International, 2(1), 1-18.

Moçoşoğlu, B. and Kaya, A. (2020). Investigation of Teachers' Attitudes Towards Distance Education Applied Due to Coronavirus Disease (COVID-19) Kahramanmaras Sutcu Imam University Journal of Education, 2(1), 15-43.

Moore, M. (1997). Theoretical Principles of Distance Education, Routledge, 22-38. Retrieved from http://www.c31.uni-oldenburg.de/cde/found/moore93.pdf

Mukhter, I. and Chowdhary, R. (2020). Teaching during covid-19: teacher and students' experience. Space and Culture, 8(2), 25. https://doi.org/10.20896/saci.v8i2.1068

Nalaskowski, F. (2020). Indoor education in Poland during the covid-19. Dialogo Journal, 6(2), 57-62. DOI: 10.18638/dialogo.2020.6.2.4

Nambiar, D. (2020). The impact of online learning during covid-19: students' and teachers' perspective. The International Journal of Indian Psychology, 8(2), 783-793. DOI: $10.25215 / 0802.094$

Ng, K., Klavina, A., Ferreira, J. P., Barrett, U., Pozeriene, J., \& Reina, R. (2021). Teachers' preparedness to deliver remote adapted physical education from different european perspectives: updates to the european standards in adapted physical activity. European Journal of Special Needs Education, 36(1), 98-113. 
Noor, S., Isa, F., \& Mazhar, F. F. (2020). Online teaching practices during the covid-19 pandemic. Educational Process: International Journal (EDUPIJ), 3:169-184. DOI: 10.22521/edupij.2020.93.4

Osmanoğlu, A. E. (2020). Social studies teachers' views on televisional distance education. Journal of Current Researches on Educational Studies, 10 (1), 67-88.

Phillips, S. A. (2020). Middle school teachers making sense of education during the covid-19 pandemic. The Journal of Advancing Education Practice, 1(1). Retrieved from https://openriver.winona.edu/jaep/vol1/iss1/4

Prensky, M. (2009). H. sapiens digital: From digital immigrants and digital natives to digital wisdom. Innovate: Journal of Online Education, 5(3).

Sarı, T. and Nayır, F. (2020). Challenges in distance education during the (covid-19) pandemic period. Qualitative Research in Education, 9(3), 328-360. doi:10.17583/qre.2020.5872

Sengir, C. (2019). The investigation of secondary school teachers' use of information technologies in terms of some variables (Istanbul Fatih district example). Istanbul Kültür University, Department of Educational Administration and Planning, Master's Thesis, Turkey.

Sezgin, S. (2021). Analysis of the emergency remote education process: featured terms, problems and lessons learned. Anadolu University Journal of Social Sceinces, 21(1), 273-296. Retrieved from https://www.researchgate.net/publication/350376832_Acil_Uzaktan_Egitim_Surecini n_Analizi_One_Cikan_Kavramlar_Sorunlar_ve_Cikarilan_Dersler

Shraim, K. and Crompton, H. (2020). The use of technology to continue learning in Palestine disrupted with covid-19. Asian Journal of Distance Education, 15(2), 1-20. https://doi.org/10.5281/zenodo.4292589

Sirakaya, M. (2019). Technology acceptance of primary and secondary school teachers. Inonu University Journal of the Faculty of Education, 20(2), 578-590. DOI: 10.17679/inuefd.495886

Teymori, A. N. and Fardin, M. A. (2020). Covid-19 and educational challenges: a review of the benefits of online education. Ann Mil Health Sci Res., 2020 September; 18(3), 1-4. DOI: 10.5812/amh.105778

Trust, T. and Whalen, J. (2021). K-12 teachers' experiences and challenges with using technology for emergency remote teaching during the COVID-19 pandemic. Italian Journal of Educational Technology, Special Issue. Retrieved from https:// ijet.itd.cnr.it/article/view/1192.

Turkish Ministry of National Education (2020a). Uzaktan Eğitim 30 Nisan'a Kadar Devam Edecek. [Distance Education Shall Continue until April the $30^{\text {th }}$ ] Retrieved from https://www.meb.gov.tr/uzaktan-egitim-30-nisana-kadar-devamedecek/haber/20585/tr

Turkish Ministry of National Education (2020b). Uzaktan Eğitim 31 Mayıs'a Kadar Devam Edecek. [Distance Education Shall Continue until May the $31^{\text {st }}$ ] https://www.meb.gov.tr/uzaktan-egitim-31-mayisa-kadar-devamedecek/haber/20803/tr

Turkish Ministry of National Education (2020c). Millî Eğitim İstatistikleri Örgün Eğitim 20192020. [National Educational Statistics: Formal Learning 2019-2020] Retrieved from https://sgb.meb.gov.tr/www/icerik_goruntule.php?KNO=396

Turkish Ministry of National Education (2020d). "EBA Asistan" Uzaktan Eğitimde Cevapsiz Soru Birakmayacak. ["EBA Assistant" will leave no questions unanswered in distance education] Retrieved from https://www.meb.gov.tr/eba-asistan-uzaktan-egitimdecevapsiz-soru-birakmayacak/haber/20829/tr 
Turkish Ministry of National Education (2020e). "EBA Kontrol Merkezi" İle Uzaktan Eğitim $7 / 24$ Yakın Takipte. [Distance education monitored closely around the clock with the "EBA Control Center"] Retrieved from https://www.meb.gov.tr/eba-kontrol-merkeziile-uzaktan-egitim-724-yakin-takipte/haber/20599/tr

Turkish Ministry of National Education (2020f). Görme Engelli Öğrencilerimiz İçin Metinleri Braille Alfabesine Çeviren Program Ücretsiz Olarak Kullanımda. [Free Software for Translating Text into Braille for Vision Impaired Students has been launched] Retrieved from https://www. meb.gov.tr/gorme-engelli-ogrencilerimiz-icin-metinleri-braillealfabesine-ceviren-program-ucretsiz-olarak-kullanimda/haber/20630/tr

Turkish Statistical Institute (2020). Hanehalkı Bilişim Teknolojileri (BT) Kullanım Araştırmas1, 2020. [Household IT Usage Research, 2020] Retrieved from https:// data.tuik.gov.tr/Bulten/Index?p=Hanehalki-Bilisim-Teknolojileri-(BT)-KullanimArastirmasi-2020-33679

Wilson, R. and Mude, W. (2020). Australian schools are closing because of coronavirus, but should they be? Retrieved from https://theconversation.com/australian-schools-areclosing-because-of-coronavirus-but-should-they-be-133432

World Bank (2020). How Countries Are Using Edtech (including Online Learning, Radio, Television, Texting) To Support Access To Remote Learning During The COVID-19 Pandemic. Retrieved from https://www.worldbank.org/en/topic/edutech/brief/howcountries-are-using-edtech-to-support-remote-learning-during-the-covid-19-pandemic

Xie, X., Siau, K., \& Nah, F. F. (2020) COVID-19 pandemic - online education in the new normal and the next normal. Journal of Information Technology Case and Application Research, 22(3), 175-187, DOI: 10.1080/15228053.2020.1824884

UNESCO (2020). Covid-10 Impact on Education. Retrieved from https://en.unesco.org/covid19/educationresponse

Y1lmaz, H. (2012). Evaluation of the attitudes of teachers in the use of technology in education (Sample of Sisli Industrial Vocational High School). Master's Thesis, Bahçeşehir University, Graduate School of Natural and Applied Sciences, Turkey. 